\title{
EFEKTIVITAS PEMBELAJARAN MATEMATIKA DENGAN \\ PENDEKATAN PROBLEM BASED LEARNING DAN MOTIVASI \\ TERHADAP HASIL BELAJAR PESERTA DIDIK KELAS V \\ SD NEGERI 113 PEKANBARU
}

\author{
Mulyati, Firman, Yanti Fitria \\ Email: firman@konselor.org
}

\begin{abstract}
ABSTRAK
Penelitian ini berawal dari masalah yang terjadi di Kelas V SD Negeri 113 Pekanbaru, yaitu hasil belajar peserta didik. Hal ini terlihat dari hasil observasi dan analisis terhadap hasil UTS I peserta didik. Penelitian ini bertujuan untuk mengungkap.1) Hasil belajar matematika peserta didik kelas V SD Negeri 113 Pekanbaru yang diajarkan dengan menggunakan pendekatan PBL lebih tinggi dibandingkan hasil belajar peserta didik dengan pendekatan konvensional. 2) Hasil belajar matematika siswa yang bermotivasi tinggi yang diajarkan menggunakan pendekatan Problem Based Learning (PBL) lebih tinggi dibandingkan hasil belajar peserta didik dengan pendekatan konvensional. 3) Hasil belajar matematika peserta didik yang bermotivasi rendah yang diajarkan menggunakan pendekatan Problem Based Learning (PBL) lebih tinggi dibandingkan hasil belajar dengan pendekatan konvensionalefektivitas pendekatan Problem Based Learning (PBL) terhadap hasil belajar peserta didik yang bermotivasi tinggi dan peserta didik yang bermotivasi rendah di kelas V SD. Jenis penelitian yang digunakan adalah quasi eksperimen dengan rancangan the static camparison: randomized control group only design. Populasi dalam penelitian ini adalah seluruh peserta didik kelas V SD Negeri 113 Pekanbaru dengan sampel kelas V A sebagai kelas kontrol dan V B sebagai kelas eksperimen. Pengambilan sampel dilakukan secara random. Data penelitian dikumpulkan melalui angket motivasi belajar dan hasil belajar peserta didik.Hipotesis yang diajukan diuji dengan menggunakan uji-t,uji-f dan uji-u. Berdasarkan temuan disimpulkan sebagai berikut ini. 1) terdapat perbedaan hasil belajar yang signifikan bagi peserta didik yang diajar menggunakan pendekatan PBL dengan pendekatan konvensional. Berdasarkan perhitungan diperoleh $t_{\text {hitung }}$ adalah 2, 984 besar dari $t_{\text {tabel }}$ 1,674 sehingga $\mathrm{H}_{1}$ diterima. 2) terdapat perbedaan hasil belajar yang signifikan bagi peserta didik yang bermotivasi tinggi diajar menggunakan pendekatan PBL dengan pendekatan konvensional. Berdasarkan perhitungan diperoleh dilihat nilai $t_{\text {hitung }}$ adalah 0,803 kecil dari $t_{\text {tabel }} 1,674$ sehingga $\mathrm{H}_{\mathrm{o}}$ diterima. 3) terdapat perbedaan hasil belajar yang signifikan bagi peserta didik yang bermotivasi rendah diajar menggunakan pendekatan PBL dengan pendekatan konvensional. Berdasarkan perhitungan diperoleh uji-u nilai $Z_{\text {hitung }}$ adalah $-3,565$ dan signifikansi $0,000<0,05$ sehingga $\mathrm{H}_{1}$ diterima.
\end{abstract}

Kata Kunci: Pendekatan PBL, motivasi, hasil belajar 


\begin{abstract}
Mulyati, 2016. "The Effective of Learning Mathematics by Using Problem Based Learning Approach And Motivation Toward the Learning Achievement of Fifth Grade Students of SDN 113 Pekanbaru". Thesis. Master Degree Program, State Universityof Padang.
\end{abstract}

This research based on the problems faced by the fifth grade students of SDN 113 Pekanbaru which are students' score achievement. It can be seen from the result observation and analysis toward the first mid test. This aim of the research is to determine 1). The math result of fifth grade students of SDN 113 Pekanbaru by using Problem Based Learning Approach and by using conventional approach. 2) Students'learning achievement that has high motivation by using Problem Based Learning Approach is higher than those who studied with Conventional Approach. 3). The students' learning achievement who has low motivation that taught by Problem Based Learning Approach will be higher than those who studied with Conventional Approach. This type of research was a quasiexperimental design with the static camparison: randomized control group only design. The population in this study were all fifth grade students of SD Negeri 113 Pekanbaru with a sample class as a class V A and V B control as the experimental class. Sampling was done randomly. Data were collected through questionnaires learning motivation and learning outcomes of students. The proposed hypothesis was tested by using t-test, f-test and u-test. The hypothesis used t-test,f-test and u-test. Based on the research as follow: 1) there is a significant differences between students' achievement by using Ploblem Based Learning Approach than using conventional way. The calculation gained that tcalculated is 2,984 is bigger than t-table 1,674 , therefore $H_{1}$ is accepted. 2) there is a significant difference between student't achievement who have high motivation taught by using Problem Based Learning than conventional one. Based on the calculation, $\mathrm{t}$-calculated is 0,803 is smaller than t-table which is 1,674 that makes $\mathrm{H}_{\mathrm{o}}$ is accepted. 3) there is a significant difference between students' achievement who low motivation taught by using Problem Based Learning than conventional one where u-testz-calculated is $-3,565$ and Significant is 0,000 smaller than Sig 0,05 which makes $\mathrm{H}_{1}$ is accepted.

Keywords: Problem Based Learning Approach, Motivation, Students' Result.

\section{PENDAHULUAN}

Matematika merupakan salah satu ilmu dasar dan juga digunakan langsung dalam kehidupan seharihari. Matematika adalah disiplin ilmu yamg menuntun kemapuan berpikir logis, analitis, sistematis, kritis, kreatif dan inovatif. Suherman(2005: 25) mengatakan bahwa "matematika adalah ratu dan pelayan ilmu". Dengan perkataan lain bahwa banyak ilmu-ilmu yang penemuan dan pengembangannya bergantung dari matematika.Peserta didik terbiasa 
berfikir secara matematika akan mudah berfikir secara logis dan rasional.

Guru sebagai ujung tombak pembelajaran matematika di sekolah harus mampu melakukan inovasi pembelajaran dan memotivasi peserta didik untuk belajar aktif, kreatif, dan sistematis dalam menemukan pengetahuan secara mandiri.

Pembelajaran matematika di SD selama ini menunjukkan bahwa penggunaan motode konvensional sangat dominan dan belum sesuai dengan tuntutan Kurikulum Tingkat Satuan Pendidikan. Dalam proses pembelajaran guru belum melibatkan peserta didik secara penuh, proses pembelajaran masih berpusat kepada guru, guru belum memberikan pengalaman, Penerapan metode konvensioanal dilakukan dalam bentuk ceramah, tanya jawab, dan pemberian tugas. Secara praktis dapat digambarkan guru memberikan penjelasan kepada peserta didik dan peserta didik mencatat disertai tanya jawab seperlunya, kemudian dilanjutkan dengan pemberian contoh soal dan latihan. Dalam proses pembelajaran peran guru sangat dominan, baik dalam menyiapkan, menyusun dan memprogram proses pembelajaran dikelas. Kondisi pembelajaran berpusat kepada guru, guru aktif dan peserta didik cendrung pasif sehingga proses pembelajaran kurang melibatkan peran peserta didik secara fisik maupun mental dalam kegiatan pembelajaran. Peserta didik sebagai subjek belajar diprogram agar memperoleh hasil belajar yang lebih baik, tapi kenyataannya peserta didik digambarkan sebagai salah satu objek dalam pembelajaran. Proses pembelajaran yang demikian mendorong peserta didik bersikap pasif, malas, bosan, masa bodoh dan mengantuk sehingga hasil belajar rendah.

Pendekatan pembelajaran secara konvensioanal yang selama ini digunakan para guru dengan menggunakan metode ceramah, pemberian latihan dan tugas kepada peserta didik belum banyak perubahan dalam meningkatkan hasil belajar matematika peserta didik. Model pembelajaran ini kurang memberikan kesempatan kepada peserta didik untuk membangun pengetahuannya sendiri melalui aktifitas-aktifitas dalam mencari dan menemukan pengetahuan baru dan pemecahan masalah matematika.

Bardasarkan data hasil belajar yang diperoleh peserta didik dalam pelajaran matematika masih rendah, karena masih banyak peserta didik yang berada di bawah Kriteria Ketuntasan Minimun (KKM) yang telah ditetapkan. Untuk mengatasi permasalahan yang dihadapi maka guru harus mengambil keputusan untuk memilih pendekatan pembelajaran yang sesuai untuk diterapkan dalam pembelajaran.

Salah satu komponen yang mempengaruhi hasil belajar peserta didik adalah motivasi belajar peserta didik. Motivasi pada dasarnya dapat membantu dalam memahami dan menjelaskan perilaku individu, termasuk individu yang sedang belajar. Ada beberapa peran penting dari motivasi dalam belajar dan pembelajaran antara lain dalam menentukan hal-hal yang dapat dijadikan penguat belajar, tujuan 
belajar dan menentukan ketekunan belajar.

Berangkat dari kondisi dan beberapa masalah pembelajaran yang ada, diperlukan adanya upaya guru secara terus menerus dan sistimatis untuk meningkatkan efektifitas pembelajaran matematika. Salah satu upaya yang dapat dilakukan adalah perlu diterapkannya pembelajaran yang memberi kesempatan luas kepada peserta didik yang langsung mengarahkan kepada pemecahan masalah dan dapat meningkatkan motivasi peserta didik, menyenangi belajar matematika dan mempunyai sikap positif terhadap matematika maka, untuk menciptakan suatu pembelajaran yang bermakna bagi peserta didik dalam belajar. Pendekatan pembelajaran yang berorientasi pada pendekatan mengatasi masalah di atas adalah dengan menggunakan pendekatan Ploblem Based Learning (PBL). Pendekatan Problem Based Learning adalah pembelajaran berbasis pada proses penyelesaian masalah dan memberikan kesempatan kepada peserta didik untuk belajar menggunakan daya pikir, kreativitas berpikir secara efektif dan efisien.

Pembelajaran pendekatan

Problem Based Learning memuat langkah-langkah yang koheren dengan proses pemecahan masalah. Polya(1981) mengajukan empat tahap strategi pemecahan masalah yaitu: (1) memahami masalah, (2) menyusun rencana pemecahan, (3) menjalankan rencana pemecahan, (4) menguji kembali penyelesaian yang diperoleh. Dwiyogo (2000) menemukan bahwa proses pemecahan masalah yang dilakukan oleh pembelajar mencakup tahap- tahap memahami masalah, merepresentasi masalah, menentukan Pendekatan, melakukan kalkulasi, dan menyimpulkan jawaban.

Berdasarkan identifikasi masalah maka penelitian ini dibatasi pada pendekatan PBL, motivasi tinggi dan rendah dan hasil belajar kognitif peserta didik dalam pembelajaran matematika. Peneliti akan melaksanakan penelitian menggunakan Pendekatan PBL pada pelajaran matematika untuk melihat pengaruh pendekatan PBL terhadap hasil belajar peserta didik yang memiliki motivasi tinggi dan motivasi rendah.

Tujuan penelitian ini yaitu mengungkapkan (1) Hasil belajar matematika peserta didik kelas V SD Negeri 113 Pekanbaru yang diajarkan dengan menggunakan pendekatan PBL lebih tinggi dibandingkan hasil belajar peserta didik dengan pendekatan konvensional. (2) Hasil belajar matematika siswa yang bermotivasi tinggi yang diajarkan menggunakan pendekatan Problem Based Learning (PBL) lebih tinggi dibandingkan hasil belajar peserta didik dengan pendekatan konvensional. (3)Hasil belajar matematika peserta didik yang bermotivasi rendah yang diajarkan menggunakan pendekatan Problem Based Learning (PBL) lebih tinggi dibandingkan hasil belajar dengan pendekatan konvensional.

Pendekatan PBL merupakan salah satu pendekatan pembelajaran inovatif yang berangkat dari masalah dunia nyata peserta didik untuk belajar tentang cara berpikir kritis dalam memecahkan suatu permasalahan. Ronis (2009:7) 
"Problem based learning is based on the idea that individuals fashion their understanding largely throught what the experience". inquiry, Pendekatan ini bercirikan penggunaan masalah kehidupan nyata sebagai sesuatu yang harus dipelajari peserta didik untuk melatih dan meningkatkan keterampilan berpikir kritis di mana tugas guru harus mempokuskan diri untuk membantu peserta didik mencapai keterampilan mengarahkan diri.

Tujuan pendekatan PBL menurut Amir (2010:27) yaitu "(1) menjadi lebih ingat dan meningkat pemahamannya atas materi ajar, (2)meningkatkan fokus pada pengetahuan yang relevan, (3)mendorong untuk berpikir, (4)membangun kerja tim, (5)membangun kecakapan belajar, (6) memotivasi pembelajar". Sejalan dengan itu Rusman (2012:238) menyatakan tujuan pendekatan PBL adalah "penguasaan isi belajar dari disiplin heuristic dan pengembangan keterampilan pemecahan masalah".

Berdasarkan beberapa pendapat ahli di atas, maka dapat disimpulkan bahwa pendekatan PBL bertujuan untuk menumbuhkan keyakinan dan kemampuan berpikir dalam diri peserta didik tentang memecahkan jawaban dari suatu masalah melalui diskusi kelompok.

Pendekatan Konvensional

Pendekatan konvensional dalam penelitian ini adalah pembelajaran yang lazim dilakukan dalam pembelajaran yang biasanya didominasi oleh guru, dimana guru terlalu banyak berperan sedangkan peserta didik pada umumnya pasif. Peserta didik hanya menerima materi yang dijelaskan guru dan mencatat apa yang telah dijelaskan oleh guru.

Uno (2011:99) mengemukakan "Metode pembelajaran melalui ceramah adalah metode yang menghendaki peserta didik harus mendapat informasi yang sama dalam jumlah peserta didik yang banyak". Selanjutnya Abimanyu (2008:3) mengemukakan "Metode ceramah adalah penyajian pelajaran oleh guru dengan cara memberikan penjelasan secara lisan kepada peserta didik. Penggunaan metode ceramah sangat tergantung pada kemampuan guru".

Berdasarkan pendapat ahli di atas dapat disimpulkan bahwa pendekatan konvensional sangat tergantung kepada kemampuan guru, karena gurulah yang berperan penuh dalam proses pembelajaran. Penguasaan guru terhadap materi pelajaran, kemampuan berbahasa dan intonasi suara sangat menentukan pelaksanaan metode ceramah pada pendekatan konvensional.

Uno (2008:31), menjelaskan motivasi adalah dorongan dasar yang menggerakkan seseorang bertingkah laku. Dorongan ini berada pada diri seseorang yang akan menggerakkan untuk melakukan sesuatu yang sesuai dengan dorongan dirinya. Oleh karena itu perbuatan seseorang yang didasarkan atas motivasi tertentu mengandung tema sesuai dengan motivasi yang mendasarinya. Sedangkan menurut Ary Ginanjar (2005:134), sumber motivasi itu berasal dari hakekat penciptaan manusia dan alam semesta, dimana setiap peserta didik memiliki kecerdasan omosional yang berbeda- 
beda yang berperan penting dalam keberhasilan belajar dan menentukan prestasi belajar peserta didik. Prestasi belajar merupakan salah satu indikator proses belajar yang dicapai peserta didik.

Hasil belajar merupakan tolak ukur untuk melihat keberhasilan peserta didik dalam menguasai materi pelajaran yang disampaikan selama pembelajaran. Hal ini akan ditentukan dengan terjadinya perubahan tingkah laku pada peserta didik setelah proses pembelajaran berakhir. Hasil belajar merupakan kemampuan berupa keterampilan dan perilaku baru sebagai akibat latihan atau pengalaman. Hasil belajar peserta didik dapat dilihat dari kemampuannya dalam mengingat pelajaran yang telah disampaikan selama pembelajaran dan bagaimana peserta didik tersebut bisa menerapkannya serta mampu memecahkan masalah yang timbul sesuai dengan apa yang telah dipelajarinya.Dalam tesis ini penilaian dilakukan pada aspek kognitif saja yang ditekankan pada penerapan /aplikasi (C3).

\section{METODE PENELITIAN}

Penelitian ini dilaksanakan di SD Negeri 113 Pekanbaru. Subjek dari penelitian ini adalah peserta didik kelas VA, dan peserta didik kelas VB tahun ajaran 2015/2016.

Penelitian ini diadakan
dengan menggunakan metode
kuantitatif, the static camparison:
randomized only control group
design (Yusuf, 213:191). Sampel
yang diambil menggunakan teknik
Random Sampling (pengambilan
secara acak), dimana diambil dua

kelas yang diklasifikasikan sama. Untuk menentukan kelas mana yang akan menjadi lokasi penelitian, diambil kelas yang memiliki rata-rata kelas nilai matematika yang setara. Variabel terdiri dari (1) variabel bebas adalah pendekatan PBL, (2) variabel terikat adalah hasil belajar kognitif peserta didik dan (3) variabel moderator adalah motivasi belajar peserta didik.

Pengukuran pada pada penelitian ini dilakukan uji validitas dan reliabilitas instrument dengan teknik menggunakan lembar uji coba instrumen penelitian. Data yang telah diperoleh dilanjutkan ke dalam teknik analisis data, yang bertujuan untuk menguji hipotesis.

\section{HASIL BELAJAR}

Deskripsi data motivasi belajar peserta didik pada kelas eksperimen yang menggunakan pendekatan PBL dan motivasi peserta didik pada kelas kontrol. Data mengenai motivasi belajar peserta didik diperoleh melalui angket motivasi belajar peserta didik pada kelas sampel.

Untuk lebih jelas dapat dilihat pada gambar:

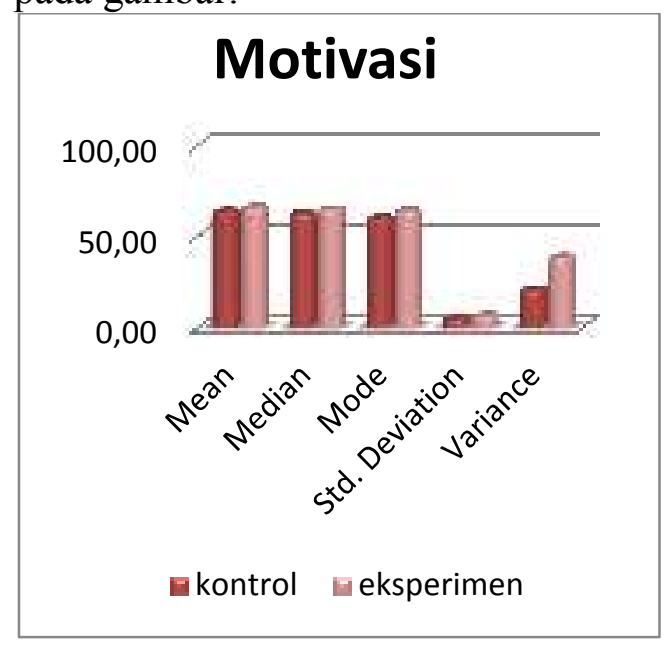


Dari gambar dapat dilihat hasil motivasi peserta didik pada pada kelas eksperimen lebih tinggi dari pada kelas kontrol. rata-rata (mean) 65,6429, nilai tengah (median) 65,0000 , skor pernyataan yang sering muncul (mode) 64,00, simpanan baku (standar deviasi) 6,20164. Data yang diperoleh pada kelas kontrol rata-rata (mean) 63,6071,nilai tengah (median) 62,5000, skor pernyataan yang sering muncul (mode) 60,00, simpanan baku (standar deviasi) 4,56508.

Untuk lebih jelas tentang distribusi skor data hasil angket motivasi peserta didik dapat dilihat pada tabel:

\section{Statistics}

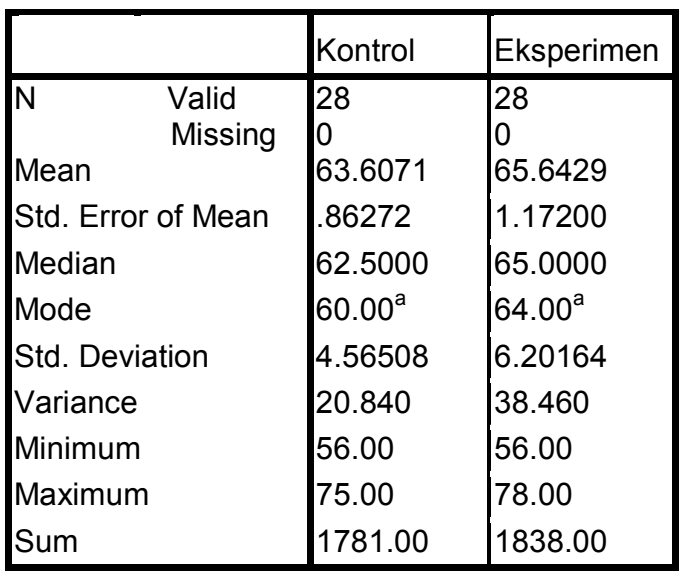

Kriteria penentuan kelompok tinggi dan rendah dapat dilihat dari tabel dibawah ini :

\begin{tabular}{|c|c|}
\hline Batas Nilai & Keterangan \\
\hline $\mathrm{X} \geq \mathrm{x}$ & Kelompok tinggi \\
\hline $\mathrm{X}<\mathrm{x}$ & Kelōmpok rendah \\
\hline
\end{tabular}

(Sumber: Modifikasi dari Arikunto( dalam Diana 2015:30)

Hasil belajar peserta didik yang memiliki motivasi tinggi dan rendah pada kelas sampel. Deskripsi data penelitian dan variabel hasil belajar secara keseluruhan mengungkapkan informasi tentang, rerata standar deviasi, modus dan median. Untuk gambaran hasil tes belajar peserta didik dapat dilihat pada gambar:

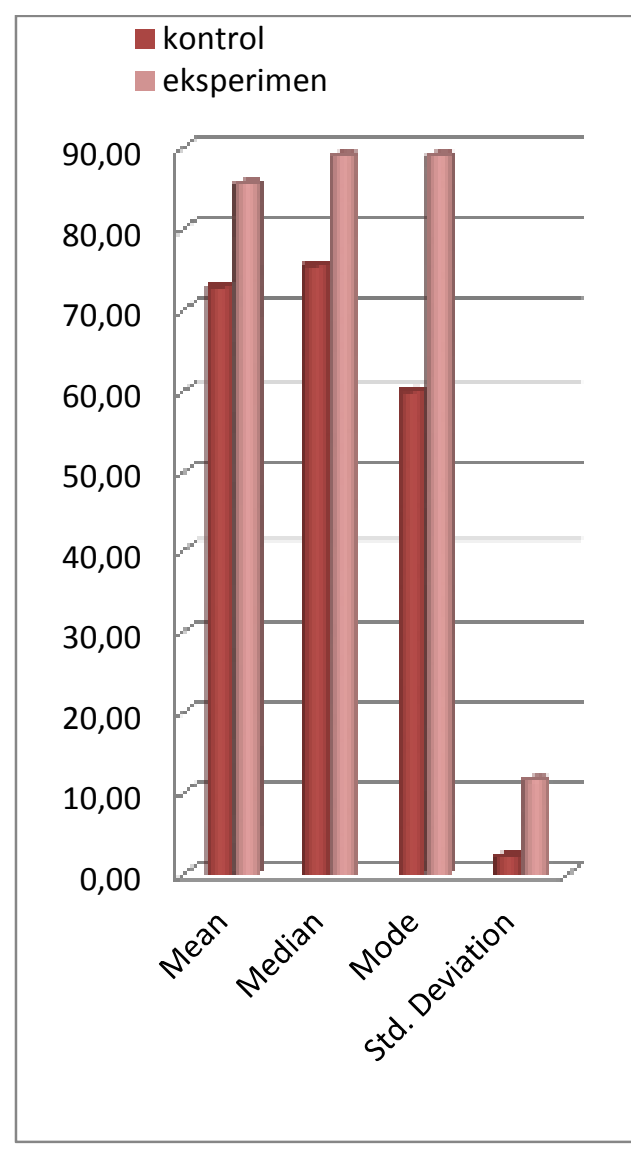

Data hasil belajar dari kedua kelas sampel pada gambar di atas pada kelas eksperimen memperoleh ratarata(mean) 85,5357, nilai tengah (median) 89,0000, mode 89,00, dan standar deviasi 11,60294 lebih besar dari kelas kontrol rata-rata (mean) 72,8571, nilai tengah (median) 75,5000, mode 60,00 dan standar deviasi 11,60294. Maka hasil belajar peserta didik pada kelas eksperimen lebih tinggi dari pada hasil belajar peserta didik pada kelas kontrol dengan selisih rata-rata sebesar 12, 9786. Profil dari keseluruhan tertera pada tabel :

\begin{tabular}{|l|l|r|r|}
\hline \multicolumn{3}{|l|}{ Statistics } \\
\hline & & Konrtol & Eksperimen \\
\hline $\mathrm{N}$ & Valid & 28 & 28 \\
\hline
\end{tabular}




\begin{tabular}{|l|r|r|}
\hline & 0 & 0 \\
\hline Mean & 72.8571 & 85.5357 \\
\hline Std. Error of Mean & 4.15211 & 2.19275 \\
\hline Median & 75.5000 & 89.0000 \\
\hline Mode & 60.00 & $89.00^{\mathrm{a}}$ \\
\hline Std. Deviation & $2.19709 \mathrm{E} 1$ & 11.60294 \\
\hline Variance & 482.720 & 134.628 \\
\hline Range & 83.00 & 34.00 \\
\hline Minimum & 17.00 & 66.00 \\
\hline Maximum & 100.00 & 100.00 \\
\hline Sum & 2040.00 & 2395.00 \\
\hline
\end{tabular}

a. Multiple modes exist. The smallest value is shown

Tabel menggambarkan tentang data hasil belajar dari kedua kelas sampel. Peserta didik pada kelas eksperimen memperoleh skor total(sum) 2.395, lebih besar dari kelas kontrol skor total (sum) 2040, maka hasil belajar peserta didik pada kelas eksperimen lebih tinggi dari pada hasil belajar peserta didik pada kelas kontrol.

\section{Uji Prasyarat Analisis}

Hasil pengujian uji normalitas untuk hasil belajar dapat dilihat pada tabel :

\begin{tabular}{|l|c|c|c|c|c|c|}
\hline \multicolumn{7}{|c|}{ Tests of Normality } \\
\hline & \multicolumn{2}{|c|}{$\begin{array}{c}\text { Kolmogorov- } \\
\text { Smirnov }\end{array}$} & \multicolumn{3}{c|}{ Shapiro-Wilk } \\
\hline & $\begin{array}{c}\text { Statisti } \\
\mathrm{c}\end{array}$ & df & Sig. & $\begin{array}{c}\text { Stati } \\
\text { stic }\end{array}$ & Df & Sig. \\
\hline Ekperimen & .120 & 28 & $.200^{*}$ & .963 & 28 & .417 \\
\hline Kontrol & .128 & 28 & $.200^{*}$ & .952 & 28 & .223 \\
\hline $\begin{array}{l}\text { a. Lilliefors Significance } \\
\text { Correction }\end{array}$ & & & \\
\hline $\begin{array}{l}\text { *. This is a lower bound of the true } \\
\text { significance. }\end{array}$ & & \\
\hline
\end{tabular}

Berdasarkan hasil uji Liliefors pada kolom Kolmogorov-Smilrnov tes uji normalitas kelas eksperimen taraf signifikansi 0,200 lebih besar dari taraf nyata 0,05 maka data tersebut dinyatakan normal dan hasil uji Liliefors tes uji normalitas kelas kontrol taraf signifikansi 0,200 lebih besar dari taraf nyata 0,05 maka data tersebut dapat juga dinyatakan normal.

Hasil pergujian uji normalitas hasil belajar peserta didik motivasi tinggi pada kelas eksperimen dan kelas kontrol dapat dilihat pada tabel

\begin{tabular}{|l|r|r|r|r|r|r|}
\hline \multicolumn{7}{|c|}{ Tests of Normality } \\
\hline & \multicolumn{2}{|c|}{$\begin{array}{c}\text { Kolmogorov- } \\
\text { Smirnov }\end{array}$} & \multicolumn{3}{|c|}{ Shapiro-Wilk } \\
\hline & $\begin{array}{c}\text { Statist } \\
\text { ic }\end{array}$ & df & Sig. & $\begin{array}{c}\text { Statisti } \\
\text { c }\end{array}$ & Df & Sig. \\
\hline eksperimen & .178 & 13 & $.200^{*}$ & .939 & 13 & .440 \\
\hline Kontrol & .194 & 13 & .195 & .913 & 13 & .200 \\
\hline $\begin{array}{l}\text { a. Lilliefors Significance } \\
\text { Correction }\end{array}$ & & & & \\
\hline $\begin{array}{l}\text { *. This is a lower bound of the true } \\
\text { significance. }\end{array}$ & & \\
\hline
\end{tabular}

Berdasarkan tabel hasil uji Liliefors pada kolom KolmogorovSmilrnov tes uji normalitas kelas eksperimen kelompok peserta didik

dengan motivasi tinggi taraf signifikansi 0,200 lebih besar dari taraf nyata 0,05 maka data tersebut dinyatakan normal dan hasil uji Liliefors tes uji normalitas kelas kontrol taraf signifikansi 0,195 lebih besar dari taraf nyata 0,05 maka data tersebut dapat juga dinyatakan normal.

Hasil pergujian uji normalitas hasil belajar peserta didik motivasi tinggi pada kelas eksperimen dan kelas kontrol dapat dilihat pada tabel:

\begin{tabular}{|l|c|c|}
\hline \multicolumn{2}{|c|}{ Tests of Normality } \\
\hline & $\begin{array}{c}\text { Kolmogorov- } \\
\text { Smirnov }^{\mathrm{a}}\end{array}$ & Shapiro-Wilk \\
\hline
\end{tabular}




\begin{tabular}{|l|r|r|r|r|r|r|}
\hline & Statistic & df & Sig. & $\begin{array}{c}\text { Statisti } \\
\text { c }\end{array}$ & Df & Sig. \\
\hline eksperimen & .212 & 13 & .112 & .830 & 13 & .016 \\
\hline Kontrol & .266 & 13 & .012 & .866 & 13 & .046 \\
\hline $\begin{array}{l}\text { a. Lilliefors Significance } \\
\text { Correction }\end{array}$ & & & \\
\hline
\end{tabular}

Berdasarkan hasil uji Liliefors pada kolom Kolmogorov-Smilrnov tes uji normalitas kelas eksperimen. Kelompok peserta didik dengan motivasi rendah taraf signifikansi adalah 0,112 lebih besar dari taraf nyata 0,05 maka data tersebut dinyatakan normal. hasil uji Liliefors tes uji normalitas kelas kontrol taraf signifikansi 0,012 lebih kecil dari taraf nyata 0,05 maka data tersebut dapat juga dinyatakan tidak normal. Karena data dari hasil tes belajar kelas rendah tidak normal maka akan dilakukan uji-u.

Uji homogenitas digunakan untuk mengetahui apakah beberapa varian populasi data sama atau tidak. Untuk menguji dilakukan prasyarat dalam analisis Indenpendent Samples T Test dan One way Anova. Perhitungan secara lengkap dapat dilihat pada tabel:

\begin{tabular}{|r|r|r|r|}
\hline \multicolumn{3}{|c|}{ Test of Homogeneity of Variances } \\
\hline Eksperimen & & & \\
\hline Levene Statistic & \multicolumn{1}{c|}{ df1 } & \multicolumn{1}{c|}{ df2 } & Sig. \\
\hline 2.358 & 7 & 11 & .098 \\
\hline
\end{tabular}

Berdasarkan analisis SPSS pada tabel uji homogenitas dapat dilihat dari output Test of Homogeneity of Variances dapat diketahui dari nilai signifikansi 0,05 $<0,098$, maka artinya bahwa kedua kelompok eksperimen mempunyai varian sama atau homogen.

\begin{tabular}{|c|c|c|c|}
\hline \multicolumn{4}{|c|}{ Test of Homogeneity of Variances } \\
\hline Kontrol & & & \\
\hline Levene Statistic & df1 & df 2 & Sig. \\
\hline
\end{tabular}

\begin{tabular}{|r|r|r|r|}
\hline \multicolumn{4}{|c|}{ Test of Homogeneity of Variances } \\
\hline Kontrol & & & \\
\hline Levene Statistic & df1 & df2 & Sig. \\
\hline 1.734 & 7 & 17 & .167 \\
\hline
\end{tabular}

Berdasarkan tabel uji homogenitas dapat dilihat dari output Test of Homogeneity of Variances dapat diketahui bahwa signifikansi 0,167 besar dari 0,05 .

Karena signifikansi lebih besar dari 0,05 maka dapat disimpulkan bahwa kedua kelompok eksperimen mempunyai varian sama dan homogen homogen.

Dalam melakukan pengujian hipotesis digunakan uji statistik dengan $U j i-t, u j i-F$ dan $U j i-U$ melalui teknik regresi sederhana. Regresi sederhana dilakukan untuk menguji hipotesis pertama, kedua dan ketiga. Pengujian dilakukan dengan menggunakan SPSS versi 16.00 Uji sua sampel Tidak berhubungan (Independent Samples $T$ Test) dengan langkah-langkah yang dilakukan dalam pengujian hipotesis regresi adalah dimulai dari Analyze, pilih Campare Maen dan selanjutnya pilih Independent Samples T Test.

Hipotesis pertama yang diuji dalam penelitian ini berbunyi hasil belajar matematika peserta didik kelas V SD yang diajarkan dengan menggunakan pendekatan PBL lebih tinggi dari hasil belajar peserta didik kelas V yang diajarkan dengan pendekatan konvensional.

Untuk lebih jelas dapat dilihat pada tabel:

Hasil perhitungan hipotesis lebih lebih jelas dapat dilihat pada tabel: 


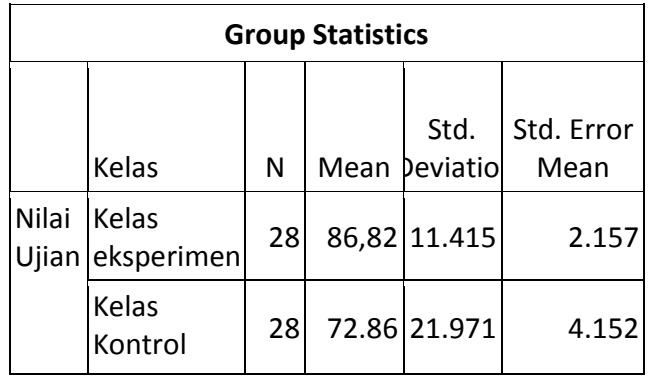

Dari dapat dilihat bahwa hasil belajar dengan nilai signifikansi 0,003 lebih kecil dari 0,05 maka $H_{0}$ ditolak dan $H_{1}$ diterima, jadi dapat disimpulkan bahwa kedua varian berbeda artinya varian kelompok eksperimen dan kontrol berbeda. Dengan ini penggunaan uji-t menggunakan Equal Variances Assumed diasumsikan kedua varian berbeda. Dan juga dari data di atas dapat dilihat nilai $t_{\text {hitung }}$ adalah 2 , 984 besar dari $t_{\text {tabel }} 1,674$ dan signifikansi 0,005 besar dari 0,0025 maka $H_{0}$ ditolak artinya bahwa ada perbedaan antara rata-rata hasil belajar kelompok yang diajarkan menggunakan pendekatan PBL dengan koelompok yang diajarkan dengan pendekatan konvensional.

Pada tabel Group Statistics terlihat rata-rata kelompok eksperimen adalah 86,82 dan untuk kelas kontrol 72,86, artinya mean dari kelompok yang diajarkan dengan pendekatan PBL lebih tinggi dari mean kelompok kontrol yang diajarkan dengan pendekatan konvensional. Nilai $t_{\text {hitung }}$ positif berarti rata-rata kelompok eksperimen lebih tinggi sedangkan perbedaan rata-rata 13.964 . Hal ini membuktikan bahwa hasil belajar peserta didik dengan pendekatan PBL lebih baik dari pada pendekatan konvensoinal pada kelas V SD Negeri 113 Pekanbaru.

\section{Pembahasan}

Pengelompokkan hasil belajar peserta didik yang memiliki motivasi kelompok motivasi tinggi dan rendah pada kelas eksperimen dan kontrol. Hasil belajar siswa pada kelas eksprerimen dan kelas kontrol yang memiliki motivasi tinggi tidak jauh berbeda dari rata-rata kelompok tinggi diperoleh 93,13 dan 91,23. Hasil belajar siswa pada kelas eksprerimen dan kelas kontrol yang memiliki motivasi rendah jauh berbeda dari rata-rata kelompok rendah diperoleh 79,54 dan 65,69.

Pada kelas eksperimen dan kelas kontrol ditemukan ada dua peserta didik masuk dalam kelompok motivasi rendah, tapi hasil belajarnya tinggi yaitu 97. Pada kelas kontrol juga ditemukan satu anak dengan motivasi rendah tapi hasil belajarnya 83.

\section{Terdapat Perbedaan Hasil Belajar Peserta Didik yang Diajar Menggunakan Pendekat- an PBL dengan Hasil Belajar Peserta Didik yang Diajar Menggunakan Pendekatan Konvensional di Kelas SD Negeri 113 Pekanbaru}

Berdasarkan perhitungan diperoleh motivasi peserta didik setelah dikonversikan tergolong pada kategori tinggi dan dan rendah. Motivasi peserta didik yang diajar menggunakan pendekatan PBL pada kategori motivasi tinggi berjumlah 15 orang peserta didik dan pada kategori rendah berjumlah 13 orang peserta didik. Motivasi peserta didik yang diajar menggunakan pendekatan konvensional pada kategori motivasi tinggi berjumlah 13 orang peserta didik dan pada 
kategori motivasi rendah berjumlah 15 orang peserta didik .

Berdasarkan hasil uji hipotesis pertama pendekatan PBL dapat meningkatkan hasil belajar peserta didik selama proses pembelajaran sesuai dengan pendapat M.Hosnan (2014: 298) adalah membantu peserta didik agar memperoleh peserta didik agar memperoleh berbagai pengalaman dan mengubah tingkah laku peserta didik, baik segi kualitas maupun kuantitas. Perubahan tingkah laku yang dimak sud meliputi pengetahuan, keterampilan dan nilai atau norma yang berfungsi sebagai pengendali sikap dan perilaku peserta didik. Peserta didik yang belajar dengan menggunakan pendekatan PBL cenderung mengalami peningkatan di tiap pertemuan, walaupun masih terdapat beberapa indikator yang mengalami penurunan di beberapa pertemuan.

\section{Terdapat Perbedaan Hasil} Belajar Peserta Didik Yang Bermotivasi Tinggi Dengan Pendekatan PBL dan Yang Diajar Menggunakan Pendekatan Konvensional Di Kelas SD Negeri 113 Pekanbaru

Hipotesis mengenai perbedaan hasil belajar peserta didik yang bermotivasi tinggi diajar meng gunakan pendekatan PBL dengan hasil belajar peserta didik yang bermotivasi tinggi diajar menggunakan pendekatan konvensional diuji mengguna-kan prorgam SPSS versi 16.00 .

Berdasarkan analisa data yang diperoleh setelah penelitian, terdapat perbedaan hasil belajar peserta didik bermotivasi tinggi yang diajar menggunakan pendekatan dengan hasil belajar peserta didik yang bermotivasi tinggi diajar menggunakan pendekatan konvensional. Hal ini dapat dilihat pada tes akhir peserta didik yang diberikan kepada kelas eksperimen dan kelas kontrol. Dengan menggunakan pendekatan PBL pada kelas eksperimen hasil belajar peserta didik meningkat. Hal itu sesuai dengan pendapat Amir (2010:27) yang menjelaskan tujuan pendekatan PBL yaitu "(1) menjadi lebih ingat dan meningkat pemahamannya atas materi ajar, (2) meningkatkan fokus pada pengetahuan yang relevan, (3)mendo rong untuk berpikir, (4)membangun kerja tim, (5)membangun kecakapan bela jar, (6) memotivasi pembelajar".

3. Terdapat Perbedaan Hasil Belajar Peserta Didik Yang Bermotivasi Rendah Dengan Pendekatan PBL dan Yang Diajar Menggunakan Pende-katan Konvensional Di Kelas SD Negeri 113 Pekanbaru

Pengujian hipotesis ketiga pada penelitian ini adalah melihat terdapat atau tidaknya perbedaan hasil belajar peserta didik yang bermotivasi rendah yang diajar menggunakan pendekatan PBL dengan hasil belajar peserta didik bermotivasi rendah yang diajar menggunakan pendekatan konvensional. Hipotesis mengenai perbedaan hasil belajar peserta didik yang bermotivasi rendah diajar menggunakan pendekatan PBL dengan hasil belajar peserta didik yang bermotivasi rendah diajar menggunakan pendekatan konvensional diuji mengguna-kan prorgam SPSS versi 16.00 .

Berdasarkan analisa data yang diperoleh setelah penelitian, terdapat perbedaan hasil belajar peserta didik 
bermotivasi rendah yang diajar menggunakan pendekatan dengan hasil belajar peserta didik yang bermotivasi rendah diajar menggunakan pendekatan konvensional. Hal ini dapat dilihat pada tes akhir peserta didik yang diberi-kan kepada kelas eksperimen dan kelas kontrol. Dengan menggunakan pendekatan PBL pada kelas eksperimen hasil belajar peserta didik meningkat. Hal itu sesuai dengan pendapat Trianto (2009:94) mengemyang menjelaskan bahwa pendekatan PBL bertujuan untuk: "(1) Membantu peserta didik mengembangkan keterampilan berpikir dan keterampilan pemecahan masalah, (2) Belajar peranan orang dewasa yang autentik, (3) Menjadi pembelajar yang mandiri.

\section{Kesimpulan}

Berdasarkan hasil penelitian dan analisis yang telah dilakukan dapat dibuat kesimpulan berikut ini :

1. Terdapat perbedaan rata-rata hasil belajar matematika siswa kelas V SD Negeri 113 Pekanbaru yang diajarkan dengan menggunakan pendekatan PBL sebesar 86,82 lebih tinggi dari rata-rata hasil belajar siswa yang diajarkan dengan pendekatan konvensional sebesar 72,86.

2. Terdapat perbedaan rata-rata hasil belajar siswa yang memiliki motivasi tinggi pada kelas eksperimen dengan pendekatan PBL sebesar 93,13 lebih tinggi dari pada siswa yang memiliki motivasi tinggi pada kelas kontrol dengan pendekatan konvensional sebesar 91,23.

3. Terdapat perbedaan hasil belajar siswa yang memiliki motivasi rendah pada kelas eksperimen dengan pendekatan PBL sebesar 79,53 lebih tinggi dari pada siswa yang memiliki motivasi rendah pada kelas kontrol dengan pendekatan konvensional sebesar 56.

Hasil penelitian menunjukkan bahwa penerapan pendekatan PBL berpengaruh terhadap hasil belajar belajar matematika. Pendekatan PBL lebih efektif diterapkan dalam belajar matematika dibandingkan dengan pendekatan konvensional untuk meningkatakan hasil belajar peserta didik. Keuntungan pendekatan PBL adalah kegiatan peserta didik selama proses pembelajaran lebih dominan, mencari informasi sendiri untuk memecahkan masalah, menimbulkan rasa puas sehingga mendorong peserta didik menemukan penemuan lagi dan aktivitas belajar peserta didik meningkat.

\section{Saran}

Berdasarkan pemaparan di atas proses pembelajaran lebih terpusat pada peserta didik sedangkan guru hanya sebagai fasilitator yang memberikan arahan kepada peserta didik. Dengan demikian pendekatan PBL dapat dijadikan sebagai salah satu alternatif untuk memperbaiki dan meningkatkan motivasi dan hasil belajar peserta didik.

Berdasarkan kesimpulan di atas dapat dikemukakan beberapa saran untuk perbaikan hasil pembelajaran, bagi guru dapat menggunakan pendekatan Ploblem Based Laerning (PBL) dalam proses pembelajaran matematika di SD, karena penerapan pendekatan (PBL) Ploblem Based Laerning dapat meningkatkan hasil belajar peserta didik, untuk kepala sekolah sebagai 
informasi dalam Pembina personil guru dalam memberikan sumbangan yang positif untuk perbaikan proses pembelajaran.

Bagi KKG untuk menyiapkan agenda untuk mengadakan pelatihan tentang penggunaan pendekatan PBL. Bagi Dinas Pendidikan supaya dapat membuat pelatihan bagi tenaga pendidik tentang PBL dan memperhatikan ketersediaan sarana dan prasarana pembelajaran untuk meningkatkan proses dan hasil pembelajaran matematika.

Penelitian ini hanya meneliti hasil belajar dengan pendekatan Ploblem Based Laerning (PBL) dan pendekatan konvensional. Untuk itu, disarankan pada peneliti selanjutnya untuk meneliti aspek-aspek lainnya, seperti kreatifitas, intelegensi dan lainnya. Bagi Peneliti lain yang berminat diharapkan mengadakan penelitian lanjutan dengan dapat mengantisipasi kendala-kendala yang terjadi.

\section{DAFTAR RUJUKAN}

Arikunto, Suharsimi. 2012. DasarDasar Evaluasi Pendidikan. Jakarta: Bumi Aksara.

Aunurrahman.2009. Belajar dan Pembelajaran. Bandung: Alfa Beta.

Beetlestone, Florence. 2011.Creative Learning. Bandung : Nusa Media

Daryanto. 2014. Pendekatan Pembelajaran Saintifik
Kurikulum 2013. Yogyakarta: Gava Media.

Depdiknas. 2006. Pedoman Penyusunan Kurikulum Tingkat Satuan Pendidikan di Sekolah Dasar. Jakarta: Badan Standar Nasional Pendidikan.

Djamarah, Syaiful Bahri. 2006. Strategi Belajar Mengajar. Jakarta: Rineka Cipta.

Dimyati dan Mudjiono. 2000. Belajar dan Pembelajaran. Jakarta: Rineka Cipta

Hamalik, Oemar.2005.Teknik Pengukuran dan Evaluasi Pendidikan.Bandung. Mandar Maju 2008.Proses Belajar Mengajar. Jakarta. Bumi Aksara

Hosnan, 2014. Pendekatan Sainstifik dan Kontektual dalam Pembelajaran Abad 21 Kunci Sukses Implementasi Kurikulum 2013. Bogor: Ghalia Indonesia

Majid, Abdul.2014. Implementasi Kurikulum 2013. Bandung : Interes Media.

Martono, Nanang. 2012. Metode Penelitian Kualitatif Analisis Isi dan Analisis data Sekunder. Jakarta: Rajagrafindo Persada.

Riduwan dan Kuncoro, E A.2012. Cara Menggunakan dan Memaknai Path Analysis (Analisis Jalur). Bandung: Alfabeta.

Ronis, Diane. 2009. Plonlem Based Learning for Math and Science 
: intergrating inquiry and the internet. USA: Skylight Professional Development.

Prayitno, Duwi.2010. Paham Analisa Statistik Data dengan SPSS. Yogyakarta: MediaKom.

Sagala, Syaiful. 2010. Konsep dan Makna Pembelajaran. Bandung: Alfabeta.

Sani, Ridwan Abdullah, 2013. Inovasi Pembelajaran. Jakarta: PT Bumi Aksara.

2014. Pembelajaran Saintifik. Jakarta: PT Bumi Aksara.

Sanjaya Wina. 2011. Strategi Pembelajaran Berorientasi Standar Proses Pendidikan Jakarta.: Prenada Media

Sardiman.2014. Interaksi\& Motivasi Belajar Mengajar. Jakarta: RajaGrafindo Persada.

Slameto. 2010. Belajar dan Faktorfaktor yang Mempengaruhinya. Jakarta: Rineka Cipta.
2012. Metode

Penelitian Kuantitatif

Kualitatif, dan Kombinasi

(Mixed Methods). Bandung: Penerbit Alfabeta

Sugiyono, 2012. Metode Penelitian Pendidikan (Kuantitatif Kualitatif, dan $R \& D)$. Bandung: Penerbit Alfabeta

Susanto,Ahmad.2013. Teori dan Pembelajaran di Sekolah Dasar. Jakarta: Prenada Media.

Uno,Hamzah B.2008. Teori Motivasi dan Pengukurannya. Jakarta: Bumi Aksara

Van de Walle, John A. 2014. Matematika Sekolah Dasar dan Menengah Jilid 1 Pengembangan Pengajaran. Jakarta: Erlangga

Yusuf, A. Muri.2005. Metode Penelitian. Padang : Penerbit UNP Press.

\section{EFEKTIVITAS PEMBELAJARAN MATEMATIKA DENGAN \\ PENDEKATAN PROBLEM BASED LEARNING DAN MOTIVASI \\ TERHADAP HASIL BELAJAR PESERTA DIDIK KELAS V \\ SD NEGERI 113 PEKANBARU}


Jurnal Tesis

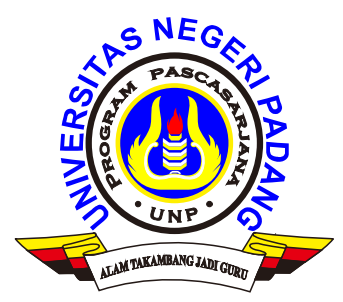

Oleh:

Mulyati

NIM.14124073

Ditulis untuk memenuhi sebagian persyaratan dalam memperoleh gelar Magister Pendidikan

\section{Disetujui oleh:}

Pembimbing I

Prof. Dr. Firman, M.S, Kons

NIP.196102251986021001
Pembimbing II

Dr. Yanti Fitria, M. Pd

NIP.19760520 2008012020
PROGRAM MAGISTER PENDIDIKAN DASAR

PROGRAM PASCASARJANA FAKULTAS ILMU PENDIDIKAN

UNIVERSITAS NEGERI PADANG

2016 
